\title{
The Impact of Protein Content of Pollen on its Collecting by Honey Bees (Apis mellifera L.)
}

\author{
Zheko Radev* \\ Bulgaria
}

ISSN: 2637-7659

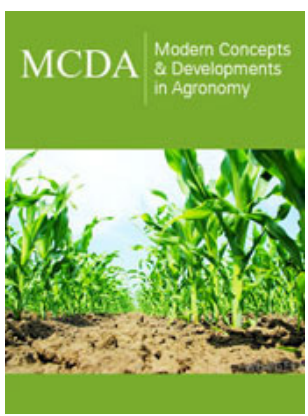

*Corresponding author: Zheko Radev, Bulgaria

Submission: 枈April 25, 2019

Published: 垉 May 08, 2019

Volume 4 - Issue 1

How to cite this article: Zheko Radev. The Impact of Protein Content of Pollen on its Collecting by Honey Bees (Apis mellifera L.). Mod Concep Dev Agrono.4(2) MCDA.000583.2019.

DOI: 10.31031/MCDA.2019.04.000583

Copyright@ Zheko Radev, This article is distributed under the terms of the Creative Commons Attribution 4.0 International License, which permits unrestricted use and redistribution provided that the original author and source are credited.

\begin{abstract}
The study results indicate, that honey bees prefer to collect pollen from 2 to 4 plants species during every single month. The honey bees had visited 46 plant species. The analysis not found difference and there is no relation between amount of collected pollen and its protein content. The choice of pollen species for collection is subject to many influences. Different colonies may utilize the local flora in different ways. The quantity collected pollen by the bees depends on the population of the certain plants that bees visit. We have to take into account the differences in the discoveries of bees-scouts, when searching for new crops, flower type, the number of flowers, bees' direct access pass, the distance to the hives, ecological factors and etc. When flowering Brassica napus, Centaurea cyanus and Centaurea solstitialis, bees collect most of them pollens. The results of the study show that the wide variety of pollen provided the taxons of naturally occurring flora, around $75 \%$ and $25 \%$ for introduced plants. It is necessary to keep and protect the native flora.
\end{abstract}

Keywords: Pollen; Protein content; Honey bee; Apis mellifera L

\section{Introduction}

The pollen loads of honey bees come in various colours, which may vary with weather conditions [1]. The percentage of pollinated plants increases with the increasing visits of the honey bees [2]. Along with this, the flow of pollen into the bee colonies increases [3-4]. Pollen dispersed by insects is commonly heavier, somewhat moist and sticky and coloured in various shades of yellow, brown, orange or red [5]. Individual colonies have a characteristic selection which may differ even between adjacent colonies [6-10]. Authors noted that the pollen collected by colonies side by side sometimes came from predominantly different sources [11,12]. Similar findings have been reported [6,13-15]. No close relationship between pollen collection and pollen phenology [7]. It seems that these differences between colonies arise partly through chance differences in the discoveries of bees-scouts, when searching for new crops. The selection of the pollen did not seem to be influenced by their age, colour, moisture or protein content. Some pollen has a greater nutritional and biological value to the honey bees than others, giving greater longevity and greater development of brood, the glands, ovaries and fat body [16]. A genetic influence is involved in preference for some pollen [17]. In France the nitrogen content of the collected pollen undergoes an annual cycle which reaches its maximum in May and June [8]. However, there is no evidence that the bees select pollen for its nutritive value. The pollen contains phytosteroles that attract the honey bees [8]. The bees collect pollen from different plants at different times of the day [18]. Pollen is a source of protein necessary for vital processes of honey bees (Apis mellifera) [19-21]. There is a relationship between the nutritional value of pollen and the development, reproduction, and productivity of the bee colonies [22]. The purpose of the study is to identify the impact of protein content of pollen on its collecting by honey bees (Apis mellifera L.).

\section{Material and Methods}

Pollen traps were placed in five bee hives and the pollen pellets were harvested every 2 days from April till September 2014 in area of Belozem (Bulgaria) $\left(42,2^{\circ} .25,033333^{\circ}\right)$. The pollen loads from each hive, were analysed carefully. Four hundred twenty samples of bee-collected pollen pellets are separated over white sheets, according to colour, shape and 
texture. The plant species of each pollen pellet is identified through microscopic examination of grains and the amount of collected pollen was weighted by an analytical scale. Melissopalynological analysis was carried out using similar methodology [23]. Each identified pollen sample was placed on a slide with a drop of isoglucose and added fuchsin. The slides were then dried in not above $40{ }^{\circ} \mathrm{C}$ and fixed with Entelan ${ }^{\mathrm{TM}}$ (Entelan Microscopy, Karlsruhe, Germany). To identify the pollen is used the database of the laboratory of Apiculture-Sericulture of the Agricultural school of Aristotle University and self-made database of the plants in the study area. The data on the protein content of pollen from different plant species were available from a previous study [24].

\section{Results and Discussion}

The data (Table 1-6) of the quantity collected pollen of honey plants with known protein content for each month during the three years are represented. During the experimental year, the honey bees prefer to collect pollen from 2-4 plants (Figure 1/ Table 1-6) species during every single month, the rest of the flora is less preferable. Figure 1 contain the data of the amount collected pollen on the most visited plant species, of which the bees collected the greatest amount of pollen, according to its protein content. A number of authors have also shown that the large amount of pollen usually comes from a small number of plant species [6,8-9,25-26], not all plants in the same area serve as a source of pollen for bees
[27]. The choice of pollen species for collection is subject to many influences. Different colonies may utilize the local flora in different ways. The pollen grains of different types of flowering plants are distinguished to each other, not only chemically but also on their physical characteristics (size, structure, adhesiveness and oth.), pollen grains vary in size with species (and to some extent with weather conditions) from less than $5 \mu \mathrm{m}$ to more than $200 \mu \mathrm{m}$, which undoubtedly affects of the speed of collection of bees, therefore the number of flights to individual bees for pollen for the day and during the season, i.e. of the common intensity of pollen-collecting. It is made statistical analysis (Excel) according to the protein content on 22 plant species and their collected amount. According to the result $y=0.002 x+20.19$ and $R^{2}=0.101$, there were not found significant differences between the amount of collected pollen and its protein content (Figure 2). It could be said that there is no relation between amount of pollens collection and their protein content. The amount of pollen that the bees collect depends on the population of the certain plants that bees visit. The results of the study show that the wide variety of pollen provide the plants of the native flora, around $75 \%$ and $25 \%$ for introduced plants. The data confirm the results of previous studies [28-30]. From an ecological point of view, it is necessary to keep the naturally distributed flora in order to ensure the normal feeding of bees and maintenance of the biodiversity.

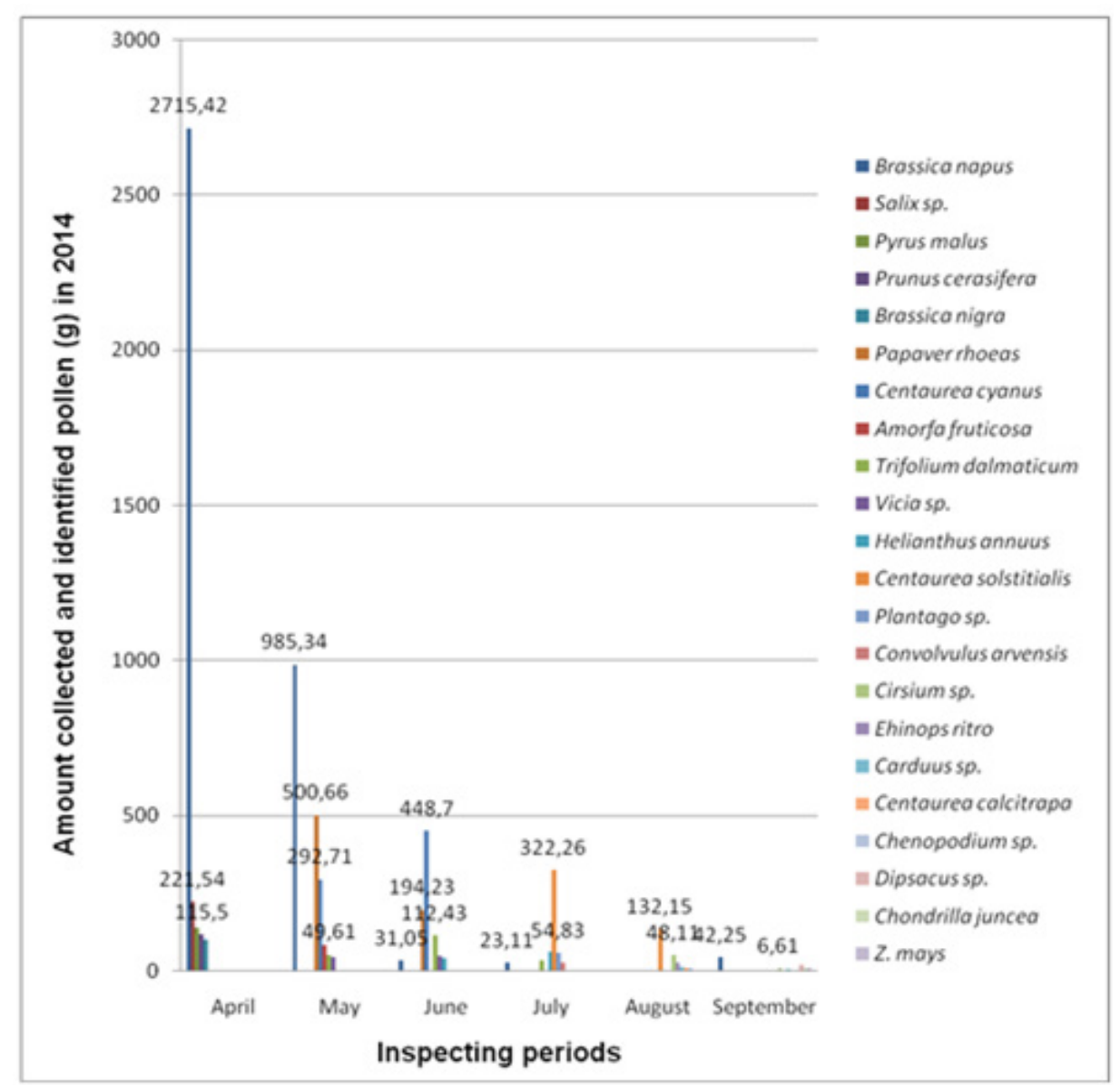

Figure 1: Amount collected and identified pollen (g) in 2014. 


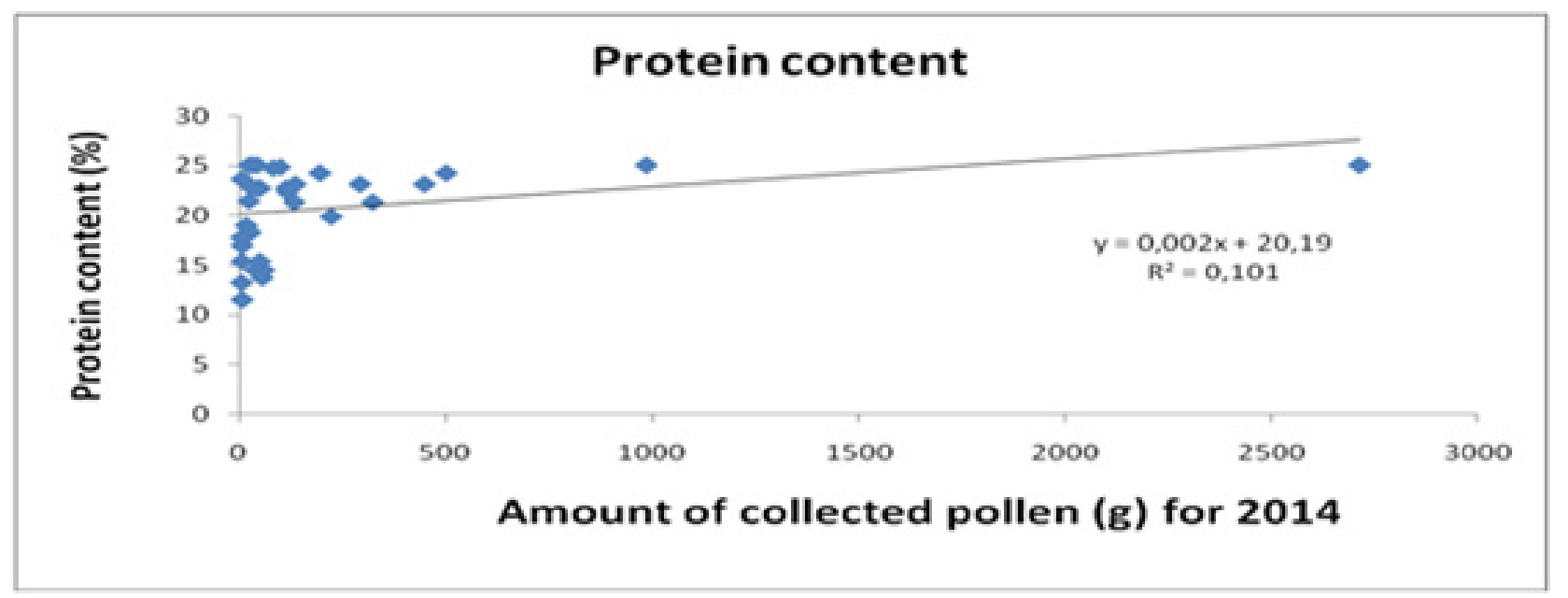

Figure 2: Amount collected pollen (g) according to its protein content (\%) for 2014.

Table 1: Amount collected and identified pollen with known protein content (g) in April 2014.

\begin{tabular}{|c|c|c|c|c|c|c|}
\hline \multirow[b]{2}{*}{ Bee colony (No) $\rightarrow$} & \multicolumn{5}{|c|}{ Amount Collected and Identified Pollen with known Protein Content of Each Bee Colony (g) } & \multirow{2}{*}{$\begin{array}{l}\text { Total Amount of } \\
\text { the Collected and } \\
\text { Identified Pollen } \\
\text { with known } \\
\text { Protein Content } \\
\text { from the Bees (g) } \\
\end{array}$} \\
\hline & No1 & No2 & No3 & No4 & No5 & \\
\hline \multicolumn{7}{|l|}{ Plant species } \\
\hline Brassica napus & 495.58 & 376.72 & 660.32 & 300.2 & 882.6 & 2715.42 \\
\hline Salix sp. & 52.65 & 52.05 & 23.87 & 33.53 & 59.44 & 221.54 \\
\hline Pyrus malus & 54.57 & 9.82 & 15.87 & 9.47 & 46.24 & 135.97 \\
\hline Prunus cerasifera & 32.53 & 23.2 & 18.46 & 10.98 & 30.33 & 115.5 \\
\hline Brassica nigra & 20.31 & 37.17 & 16.89 & 15.73 & 8.59 & 98.69 \\
\hline Juglans regia & 14.01 & 0.5 & 0.27 & 1.48 & 0.19 & 16.45 \\
\hline Morus nigra & 2.39 & 0.67 & 2.14 & 7.15 & 2.72 & 15.07 \\
\hline Cornus sanguinea & 6.25 & 2.63 & 0.8 & 2.68 & 1.85 & 14.21 \\
\hline Persica vulgaris & 3.19 & 1.36 & 2.68 & 2.7 & 1.14 & 11.07 \\
\hline $\begin{array}{l}\text { Taraxacum } \\
\text { officinale }\end{array}$ & 1.91 & 0.36 & 1.21 & 1.35 & 1.29 & 6.12 \\
\hline Lamium purpureum & 0.22 & 0.79 & 2.65 & 0.72 & 0.24 & 4.62 \\
\hline Veronica longifolia & 0.37 & 0.07 & 0.31 & & & 0.75 \\
\hline
\end{tabular}

Table 2: Amount collected and identified pollen with known protein content (g) in May 2014.

\begin{tabular}{|c|c|c|c|c|c|c|}
\hline \multirow[b]{2}{*}{ Bee colony (No) $\rightarrow$} & \multicolumn{5}{|c|}{ Amount Collected and Identified Pollen with known Protein Content of Each Bee Colony (g) } & \multirow{2}{*}{$\begin{array}{l}\text { Total Amount of } \\
\text { the Collected and } \\
\text { Identified Pollen } \\
\text { with known } \\
\text { Protein Content } \\
\text { from the Bees (g) }\end{array}$} \\
\hline & No1 & No2 & No3 & No4 & No5 & \\
\hline \multicolumn{7}{|l|}{ Plant species } \\
\hline Brassica napus & 188.57 & 88.09 & 418.21 & 68.91 & 221.56 & 985.34 \\
\hline Papaver rhoeas & 68.24 & 21.93 & 80.5 & 67.26 & 262.73 & 500.66 \\
\hline Centaurea cyanus & 111.21 & 45.67 & 106.55 & 26.45 & 2.83 & 292.71 \\
\hline Amorfa fruticosa & 6.99 & 18.45 & 18.41 & 19.24 & 17.77 & 80.86 \\
\hline $\begin{array}{c}\text { Trifilium } \\
\text { dalmaticum }\end{array}$ & 5.59 & 14.12 & 11.4 & 11.7 & 6.8 & 49.61 \\
\hline
\end{tabular}




\begin{tabular}{|c|c|c|c|c|c|c|}
\hline Vicia sp. & 9.22 & 4.83 & 9.8 & 5.32 & 13.87 & 3.97 \\
\hline $\begin{array}{c}\text { Robinia } \\
\text { pseudoacacia }\end{array}$ & 4.08 & 8.9 & 3.5 & 1.14 & 0.04 \\
\hline Trifolium repens & 0.39 & 1.22 & 7.26 & 0.04 & 0.19 & 0.49 \\
\hline Brassica nigra & 0.51 & 1.45 & 1.18 & 0.18 & 0.44 & 3.92 \\
\hline $\begin{array}{c}\text { Convolvulus } \\
\text { arvensis }\end{array}$ & 0.29 & 1.6 & 0.95 & 0.57 & 0.34 & 2.92 \\
\hline Pyrus malus & 0.12 & 1.49 & 0.4 & 0.05 & 0.24 & 1.33 \\
\hline Salix sp. & 0.25 & 0.06 & 0.73 & & 0.4 & 1.13 \\
\hline Plantago $s p$. & 0.28 & 0.14 & 0.31 & 0.26 & 0.26 & 1.01 \\
\hline Ranunculus $s p$. & 0.17 & 0.06 & 0.26 & & \\
\hline
\end{tabular}

Table 3: Amount collected and identified pollen with known protein content (g) in June 2014.

\begin{tabular}{|c|c|c|c|c|c|c|}
\hline \multirow[b]{2}{*}{ Bee colony (No) $\rightarrow$} & \multicolumn{5}{|c|}{ Amount Collected and Identified Pollen with known Protein Content of Each Bee Colony (g) } & \multirow{2}{*}{$\begin{array}{l}\text { Total Amount of } \\
\text { the Collected and } \\
\text { Identified Pollen } \\
\text { with Known } \\
\text { Protein Content } \\
\text { from the Bees (g) }\end{array}$} \\
\hline & No1 & No2 & No3 & No4 & No5 & \\
\hline \multicolumn{7}{|l|}{ Plant species } \\
\hline Centaurea cyanus & 93.94 & 66.93 & 203.58 & 51.35 & 32.9 & 448.7 \\
\hline Papaver rhoeas & 35.45 & 1.89 & 54.73 & 19.21 & 82.95 & 194.23 \\
\hline $\begin{array}{c}\text { Trifolium } \\
\text { dalmaticum }\end{array}$ & 33.68 & 20.25 & 26.35 & 13.95 & 18.2 & 112.43 \\
\hline Vicia sp. & 9.71 & 8.3 & 15.34 & 6.79 & 5.76 & 45.9 \\
\hline Helianthus annuus & 7.32 & 9.18 & 3.28 & 12.5 & 5.98 & 38.26 \\
\hline Brassica napus & 4.53 & 10.2 & 15.1 & 0.39 & 0.83 & 31.05 \\
\hline Cirsium sp. & 13.59 & 1.55 & 7.6 & 1.45 & 5.17 & 29.36 \\
\hline Plantago sp. & 8 & 10.59 & 4.12 & 0.5 & 2.88 & 26.09 \\
\hline Melilotus officinalis & 1.15 & 3.52 & 1.67 & 0.56 & 1.85 & 8.75 \\
\hline Amorfa fruticosa & 0.09 & 2.49 & 2.26 & 0.24 & 0.59 & 5.67 \\
\hline Carduus sp. & 0.18 & 1.17 & 0.43 & 0.14 & 0.33 & 2.25 \\
\hline $\begin{array}{l}\text { Coriandrium } \\
\text { sativum }\end{array}$ & 0.94 & 0.61 & & & 0.35 & 1.9 \\
\hline Trifolium repens & 1.46 & 0.08 & 0.27 & 0.07 & & 1.88 \\
\hline Tilia sp. & 0.1 & 0.16 & 0.1 & 0.18 & 0.64 & 1.18 \\
\hline Crepis sp. & 0.07 & 0.1 & 0.42 & & 0.08 & 0.67 \\
\hline Cucumis melo & 0.47 & & & & & 0.47 \\
\hline Verbascum sp. & 0.24 & 0.04 & & & & 0.28 \\
\hline $\begin{array}{c}\text { Convolvulus } \\
\text { arvensis }\end{array}$ & 0.09 & & 0.14 & & & 0.23 \\
\hline Zea mays & & & & 0.13 & & 0.13 \\
\hline
\end{tabular}

Table 4: Amount collected and identified pollen with known protein content (g) in July 2014.

\begin{tabular}{|c|c|c|c|c|c|c|}
\hline \multirow[b]{2}{*}{ Bee colony (No) $\rightarrow$} & \multicolumn{5}{|c|}{ Amount Collected and Identified Pollen with Known Protein Content of Each Bee Colony (g) } & \multirow{2}{*}{$\begin{array}{l}\text { Total Amount of } \\
\text { the Collected and } \\
\text { Identified Pollen } \\
\text { with known } \\
\text { Protein Content } \\
\text { from the Bees (g) }\end{array}$} \\
\hline & No1 & No2 & No3 & No4 & No5 & \\
\hline \multicolumn{7}{|l|}{ Plant species } \\
\hline $\begin{array}{l}\text { Centaurea } \\
\text { solstitialis }\end{array}$ & 52.77 & 24.85 & 77.5 & 107.9 & 59.23 & 322.26 \\
\hline
\end{tabular}




\begin{tabular}{|c|c|c|c|c|c|c|}
\hline Helianthus annuus & 5.24 & 6.55 & 5.77 & 14.72 & 26.33 & 58.61 \\
\hline Plantago sp. & 10.19 & 8.37 & 7.4 & 9.66 & 19.21 & 54.83 \\
\hline $\begin{array}{c}\text { Trifolium } \\
\text { dalmaticum }\end{array}$ & 6.85 & 3.74 & 10.51 & 6.48 & 4.33 & 31.91 \\
\hline Cirsium sp. & 1.03 & 2.38 & 11.7 & 3.38 & 4.62 & 23.11 \\
\hline Brassica napus & 2.03 & 5.58 & 9.53 & 2.55 & 3.23 & 22.92 \\
\hline $\begin{array}{l}\text { Convolvulus } \\
\text { arvensis }\end{array}$ & 2.61 & 0.55 & 0.23 & 8.84 & 5.34 & 17.57 \\
\hline Citrullus lanatus & 0.05 & 0.48 & 1.74 & 14.1 & & 16.37 \\
\hline Centaurea cyanus & 1.72 & 1.16 & 3.55 & 0.07 & 0.13 & 6.63 \\
\hline Ehinops ritro & 1.41 & 0.14 & 0.33 & 1.41 & 0.37 & 3.66 \\
\hline Zea mays & 0.52 & 0.38 & 0.06 & 1.8 & 0.74 & 3.5 \\
\hline Vicia sp. & 0.08 & 0.79 & 0.06 & 0.74 & 1.28 & 2.95 \\
\hline Cichorium intybus & & 0.03 & 0.1 & 1.83 & 0.67 & 2.63 \\
\hline Carduus sp. & 0.12 & 0.19 & 0.45 & 0.78 & 0.33 & 1.87 \\
\hline Verbascum sp. & 0.83 & 0.12 & 0.22 & 0.35 & 0.14 & 1.66 \\
\hline Melilotus officinalis & & 0.3 & 0.26 & 0.67 & & 1.23 \\
\hline Crepis sp. & 0.04 & 0.54 & 0.05 & 0.26 & 0.1 & 0.99 \\
\hline $\begin{array}{c}\text { Portulaca } \\
\text { grandiflora }\end{array}$ & 0.62 & 0.06 & & 0.19 & & 0.87 \\
\hline Centaurea sp. & & & 0.16 & 0.13 & 0.29 & 0.58 \\
\hline $\begin{array}{l}\text { Centaurea } \\
\text { calcitrapa }\end{array}$ & 0.04 & 0.02 & & 0.44 & 0.06 & 0.56 \\
\hline Papaver rhoeas & 0.25 & 0.12 & 0.16 & & & 0.53 \\
\hline Cucumis melo & 0.06 & 0.1 & 0.02 & 0.15 & 0.03 & 0.36 \\
\hline $\begin{array}{l}\text { Eryngium } \\
\text { campestre }\end{array}$ & & & & & 0.27 & 0.27 \\
\hline
\end{tabular}

Table 5: Amount collected and identified pollen with known protein content (g) in August 2014.

\begin{tabular}{|c|c|c|c|c|c|c|}
\hline \multirow[b]{2}{*}{ Bee colony $(\mathrm{No}) \rightarrow$} & \multicolumn{5}{|c|}{ Amount Collected and Identified Pollen with known Protein Content of Each Bee Colony (g) } & \multirow{2}{*}{$\begin{array}{l}\text { Total Amount of } \\
\text { the Collected and } \\
\text { Identified Pollen } \\
\text { with known } \\
\text { Protein Content } \\
\text { from the Bees (g) }\end{array}$} \\
\hline & No1 & No2 & No3 & No4 & No5 & \\
\hline \multicolumn{7}{|l|}{ Plant species } \\
\hline $\begin{array}{l}\text { Centaurea } \\
\text { solstitialis }\end{array}$ & 41.6 & 4.62 & 20.76 & 39.73 & 25.44 & 132.15 \\
\hline Cirsium sp. & 1.19 & 2.87 & 0.04 & 26.19 & 17.82 & 48.11 \\
\hline Ehinops ritro & 0.48 & 1.83 & 0.15 & 6.72 & 15.98 & 25.16 \\
\hline Carduus sp. & 1.13 & 1.22 & 2.84 & 0.48 & 3.75 & 9.42 \\
\hline $\begin{array}{l}\text { Centaurea } \\
\text { calcitrapa }\end{array}$ & 2.08 & 0.22 & 0.1 & 2.05 & 2.1 & 6.55 \\
\hline Chenopodium sp. & 2.14 & 0.09 & 0.12 & 0.62 & 2.59 & 5.56 \\
\hline Plantago sp. & 2.23 & 0.61 & 0.61 & 0.09 & 1.38 & 4.92 \\
\hline $\begin{array}{c}\text { Portulaca } \\
\text { grandiflora }\end{array}$ & 0.55 & 0.56 & & 1.36 & 0.25 & 2.72 \\
\hline Dipsacus sp. & 0.13 & 0.21 & 0.21 & 0.23 & 1.29 & 2.07 \\
\hline Brassica napus & 0.52 & & 0.08 & 0.75 & 0.36 & 1.71 \\
\hline Atriplex patula & & 0.17 & 0.35 & 0.53 & 0.22 & 1.27 \\
\hline Chondrilla juncea & 0.48 & 0.28 & 0.12 & 0.18 & 0.21 & 1.27 \\
\hline
\end{tabular}




\begin{tabular}{|c|c|c|c|c|c|c|}
\hline Centaurea sp. & 0.06 & 0.14 & 0.42 & 0.06 & 0.07 & 0.75 \\
\hline Vicia sp. & 0.27 & 0.07 & 0.06 & & 0.2 & 0.6 \\
\hline Cichorium intybus & 0.19 & 0.12 & 0.06 & 0.05 & & 0.42 \\
\hline $\begin{array}{l}\text { Convolvulus } \\
\text { arvensis }\end{array}$ & & & 0.32 & 0.09 & & 0.41 \\
\hline $\begin{array}{c}\text { Trifolium } \\
\text { dalmaticum }\end{array}$ & 0.07 & 0.11 & 0.05 & & 0.14 & 0.37 \\
\hline Melilotus officinalis & 0.05 & & & 0.15 & 0.06 & 0.26 \\
\hline Cucumis melo & & 0.02 & 0.11 & 0.02 & 0.03 & 0.18 \\
\hline $\begin{array}{l}\text { Eryngium } \\
\text { campestre }\end{array}$ & & & & & 0.17 & 0.17 \\
\hline Centaurea cyanus & & & 0.14 & & & 0.14 \\
\hline Lythrum salicaria & 0.05 & & 0.06 & 0.03 & & 0.14 \\
\hline Zea mays & 0.04 & & & & & 0.04 \\
\hline
\end{tabular}

Table 6: Amount collected and identified pollen with known protein content (g) in September 2014.

\begin{tabular}{|c|c|c|c|c|c|c|}
\hline \multirow[b]{2}{*}{ Bee colony $(\mathrm{No}) \rightarrow$} & \multicolumn{5}{|c|}{ Amount Collected and Identified Pollen with known Protein Content of Each Bee Colony (g) } & \multirow{2}{*}{$\begin{array}{l}\text { Total Amount of } \\
\text { the Collected and } \\
\text { Identified Pollen } \\
\text { with known } \\
\text { Protein Content } \\
\text { from the Bees (g) }\end{array}$} \\
\hline & No1 & No2 & No3 & No4 & No5 & \\
\hline \multicolumn{7}{|l|}{ Plant species } \\
\hline Brassica napus & 1.76 & 2.25 & & 35.88 & 2.36 & 42.25 \\
\hline Dipsacus sp. & 3.77 & & & 0.6 & 11.96 & 16.33 \\
\hline Chondrilla juncea & 0.33 & 0.02 & 3.2 & 2.91 & 0.34 & 6.8 \\
\hline Cirsium sp. & 0.67 & 3.01 & 0.08 & 1.39 & 1.46 & 6.61 \\
\hline Zea mays & & 0.93 & 0.48 & 5.12 & & 6.53 \\
\hline Carduus sp. & 0.69 & & 3.84 & 0.07 & 0.47 & 5.07 \\
\hline Chenopodium sp. & 0.16 & 0.12 & 2.24 & 0.47 & 0.26 & 3.25 \\
\hline $\begin{array}{l}\text { Centaurea } \\
\text { calcitrapa }\end{array}$ & 0.31 & 0.2 & 0.85 & 0.88 & 0.77 & 3.01 \\
\hline Cucumis sativus & 0.09 & 0.06 & 0.1 & 1.01 & 0.63 & 1.89 \\
\hline $\begin{array}{l}\text { Centaurea } \\
\text { solstitialis }\end{array}$ & 0.69 & & 0.45 & 0.29 & 0.03 & 1.46 \\
\hline $\begin{array}{c}\text { Portulaca } \\
\text { grandiflora }\end{array}$ & & 0.1 & 0.04 & 1.07 & 0.13 & 1.34 \\
\hline Ehinops ritro & 0.08 & 0.18 & 0.03 & 0.52 & 0.34 & 1.15 \\
\hline Centaurea sp. & 0.45 & & 0.1 & 0.07 & & 0.62 \\
\hline Cichorium intybus & & & 0.25 & 0.12 & 0.15 & 0.52 \\
\hline Verbascum sp. & 0.07 & & 0.19 & & 0.19 & 0.45 \\
\hline $\begin{array}{c}\text { Convolvulus } \\
\text { arvensis }\end{array}$ & 0.07 & & 0.22 & 0.06 & & 0.35 \\
\hline Plantago sp. & & & 0.19 & & 0.05 & 0.24 \\
\hline Atriplex patula & & & & 0.2 & & 0.2 \\
\hline Cucumis melo & & 0.02 & 0.11 & 0.02 & 0.03 & 0.18 \\
\hline $\begin{array}{l}\text { Eryngium } \\
\text { campestre }\end{array}$ & & & & & 0.17 & 0.17 \\
\hline Centaurea cyanus & & & 0.14 & & & 0.14 \\
\hline
\end{tabular}




\begin{tabular}{|c|l|l|l|l|l|l|}
\hline Lythrum salicaria & 0.05 & & 0.06 & 0.03 & & 0.14 \\
\hline Zea mays & 0.04 & & & & & 0.04 \\
\hline
\end{tabular}

\section{Conclusion}

The study results indicate, that honey bees prefer to collect pollen from 2 to 4 plants species during every single month. The honey bees had visited 46 plant species. The analysis not found difference and there is no relation between amount of collected pollen and its protein content. The quantity collected pollen by the bees depends on the population of the certain plants that bees visit. We have to take into account the differences in the discoveries of bees-scouts, when searching for new crops, flower type, the number of flowers, bees' direct access pass, the distance to the hives, ecological factors and etc. When flowering, Brassica napus, Centaurea cyanus and Centaurea solstitialis, bees collect most of them pollens. The results of the study show that the wide variety of pollen provided the taxons of naturally occurring flora, around 75\% and $25 \%$ for introduced plants. It is necessary to keep and protect the native flora.

\section{References}

1. Hodges D (1950) The pollen loads of the honeybee. Bee Research Association, London, England p.120.

2. Hobbs G, Lilly K (1955) Factors affecting efficiency of honey bees (Hymenoptera: Apidae)-as pollinators of alfalfa in Southern Alberta. Canadian Journal of Agricultural Science 35(5): 422-432.

3. Voskresenska A, Lopatina N (1952) Formation and decreasing conditioned reflexes in bees. General Biology 13: 6.

4. Tushmalova N (1958) Formation of the of the food reflex of the bees. Beekeeping 1(1): 25-29.

5. Maheshwari P (1950) An introduction to the physiology of angiosperms. McGraw-Hill, New York, USA, p. 453.

6. Maurizio A (1953) Weitere Untersuchungen an Pollenhoschen. Beih Schweiz Bienen-Ztg 20: 486-556.

7. Louveaux J (1958) Recherches cur la recolte du pollen par les abeilless (Apis mellifica L.). Annals Abeill, 1: 113-138, 197-221.

8. Louveaux J (1959) Recherches cur la recolte du pollen par les abeilless (Apis mellifica L.). Annals Abeille 2: 13-111.

9. Adams RJ, Smith MV, Townsend GF (1979) Identification of honey sources by pollen analysis of nectar from the hive. Journal of Apicultural Research 18(4): 292-297.

10. Raycheva Ts, Radev Z (2012) Floral specialization of honey bee (Apis mellifera L.) in Urban condition (Chirpan Town, Thracian Lowland). Ecology and Future 11: 78-81.

11. Todd FE, Bishop RK (1941) The role of pollen in the economy of the hive. United States Department of Agriculture Bureau of Entomology No E-536 pp. 1-9.
12. Eckert JE (1942) The pollen required by a colony of honeybees. Journal of Economic Entomology 35(3): 309-311.

13. Maurizio A (1949) Pollenanalytische Untersuchungen an Honig und Pollen-hoschen. Beich Schweiz Bienen-Ztg 18(2): 320-455.

14. Louveaux J (1954) Etudes sur la recolte du pollen par les abeilles, Apiculteur (Section scientific). 98(12): 43-50.

15. Schwan B, Martinovs A (1954) Studier over binas (Apis mellifica) pollendrag i Ultuna. Meddelande Statens Husdjursforsok 7(5): 35.

16. Maurizio A (1950) The influence of pollen feeding and brood rearing on the length of life and physiological condition of the honey bees preliminary report. Bee World 31(2): 9-12.

17. Nye WP, Mackensen O (1970) Selective breeding of honeybees for alfalfa pollen collection-with tests in high and low alfalfa pollen collection regions. Journal of Apicultural Research 9(2): 61-64.

18. Parker RL (1926) The collection and utilization of pollen by the honeybee. Bee World 8(9): 141-142.

19. Dietz A (1975) The hive and the honey bee. Nutrition of the adult honey bee. Dadant \& Sons (Ed.), Journal Printing Co., Illinois, USA, pp. 125-156.

20. Haydak MA (1935) Brood rearing by honey bees confined to a pure carbohydrate diet. Journal of Economic Entomology 28(4): 657-660.

21. Haydak MA (1937) Changes in weight and nitrogen content of adult bees under a protein free diet. Journal of Agricultural Research 54(10): 791796.

22. Radev Zh, Liolios V, Tananaki C, Thrasyvoulou A (2014) The impact of the nutritive value of pollen on the development, reproduction and productivity of honey bee (Apis mellifera L.). Bulgarian Journal of Agricultural Science 20(3): 685-689.

23. Louveaux J, Maurizio A, Vorwohl G (1978) Methods of Melissopalynology. Bee World 59(4): 139-157.

24. Radev Z (2018) Variety in protein content of pollen from 50 plants from Bulgaria. Bee World 95(3): 81-83.

25. Percival MS (1955) The presentation of pollen in certain angiosperms and its collection by Apis mellifera. New Phytology 54(3): 353-368.

26. Murrell DM, Szabo TI (1981) Pollen collection by honey bees at Beaverlodge, Alberta. American Bee Journal 121: 885-888.

27. Stanley RG, Linskens HF (1974) Pollen, Biology, Biochemistry, Management. Springer, Berlin, New York USA.

28. Radev Zh, Gospodinova M (2015) Study of the Visited Flora by Apis mellifera L. in Urban Environment: Suedinenie (central Sredna gora). Journal of Animal Science 49: 62-64.

29. Radev Zh (2015) Study of the visited Flora by Apis mellifera L. in mountain environment. I. Central Stara Planina-Radountsi. Ecology and Future 14(3): 50-52.

30. Radev Zh (2015) Study of the Visited Flora by Apis mellifera L. in urban environment. II. Danubian Plain-Topchii. Ecology and Future 14(3): 5355.

For possible submissions Click below: 